Antifreeze Admixtures for Cold Regions Concreting

\title{
A Literature Review
}

Charles J. Korhonen 
Special Report 90-32

Cold Regions Research \& Engineering Laboratory

\section{Antifreeze Admixtures for Cold Regions Concreting}

\section{A Literature Review}

Charles J. Korhonen 


\section{PREFACE}

This report was prepared by Charles J. Korhonen, Research Civil Engineer, Civil and Geotechnical Engineering Research Branch, Experimental Engineering Division, U.S. Army Cold Regions Research and Engineering Laboratory. The work was funded by the Directorate of Civil Works under Work Unit CWIS 32495, Cold Weather Concrete.

Edel Cortez and Francis Sayles of CRREL technically reviewed this report.

The contents of this report are not to be used for advertising or promotional purposes. Citation of brand names does not constitute an official endorsement or approval of the use of such commercial products. 


\title{
Antifreeze Admixtures for Cold Regions Concreting
}

\author{
A Literature Review
}

\author{
CHARLES J. KORHONEN
}

\section{INTRODUCTION}

In the United States, most winter concreting operations follow guidance provided by the American Concrete Institute on cold weather concreting (ACI 1988). This guidance was developed to ensure that fresh concrete placed at low temperatures will not freeze at an early age. The guidance recommends that fresh concrete be placed warm and on thawed surfaces. The concrete must then be kept warm by conserving its initial and internally developed heat by insulation or by heated enclosures. Protection must continue until the concrete gains sufficient strength to ensure safety. Although $\mathrm{ACI}$ recommends that protection times may be shortened by the use of rapid-setting cement, extra cement or accelerating admixtures, ACI does not recommend any other forms of freeze-protection. As a consequence, the high heating costs and the extra labor and materials often required to protect concrete from freezing can significantly add to the cost of concreting, especially in the Arctic.

In the U.S.S.R., Scandinavia, China and elsewhere, winter concreting operations are conducted in other ways. One method of winter concreting of special interest is the use of chemical admixtures to depress the freezing point of mix water. These antifreeze admixtures allow concrete to cure at below-freezing temperatures without the concrete suffering the deleterious effects of ice. Numerous compounds have been tried in these countries and some of the compounds are seen as an economical alternative to conventional concreting techniques. A few of these antifreeze admixtures are being used commercially.

This report reviews this technology, summarizes available information on the use of antifreeze admixtures and recommends needed research.

\section{EFFECTS OF BELOW-FREEZING TEMPERATURE ON CONCRETE}

Concrete is a composite material composed of cement, stone and water. It gains strength by a chemical reaction between cement and water to form a gel that hardens and binds the stone together. This chemical reaction or curing process depends very much on favorable temperature and humidity conditions. Generally, humidities above $80 \% \mathrm{RH}$ and temperatures between 10 (50) and $20^{\circ} \mathrm{C}\left(70^{\circ} \mathrm{F}\right)$ are best.

Several important events happen during below-freezing-temperature curing of concrete. They include the migration of moisture within the mix, a slowing of the reaction rate between cement and water, and the change of water into ice. Provided some water remains unfrozen, the cement will continue to hydrate at low temperatures, albeit at a slow rate. At temperatures below $-4^{\circ} \mathrm{C}$ $\left(25^{\circ} \mathrm{F}\right)$, hydration essentially stops because available water freezes and the concrete becomes dormant. As temperatures rise and ice melts, hydration resumes. However, if the concrete freezes at an early age (i.e., after it has set but before it has developed much strength), there exists the possibility of permanent damage to the concrete, even though hydration can be reestablished.

Cooling rates influence both the movement of moisture and the formation of ice within early age concrete. When such concrete is cooled rapidly, moisture has little chance to migrate and it is frozen in place. This creates a nearly uniform distribution of small ice crystals throughout the concrete. It follows that, at an early age, the $9 \%$ expansion caused by the formation of ice can disrupt the weak cement paste. Slow cooling, on the other hand, allows moisture to redistribute itself within the mix by moving toward and freezing at the colder 
areas, similar to the way water moves in freezing soils. As water continues to move toward the freezing zone, the ice thickens. In this case, the concrete can be damaged by the ice crystals forming into layers or lenses, forcing apart the aggregate and paste particles. Both slow and rapid freezing can cause concrete to experience irreparable strength loss.

\section{ANTIFREEZE TYPES}

Several types of antifreeze admixtures are reported in the literature. As early as the 1950's, the U.S.S.R. reported using large quantities of calcium chloride and sodium chloride for cold weather concreting. Though corrosion was later found to be a major drawback with these admixtures, the use of salt as a freezing point depressant opened up a "new method" of winter concreting in the U.S.S.R. (Mironov et al. 1976). Since then, interest in winter concreting has developed on an international scale. Countries such as Finland and China have reported significant findings. Finland marketed its first ready-mix antifreeze concrete in 1985 after a 4- year laboratory study based on Soviet literature. Today, Finland has at least three commercial antifreeze admixtures on the domestic market, and plans to export them to other countries.

Antifreeze admixtures are mentioned in a recent International Union of Testing and Research Laboratories for Materials and Structures (RILEM) publication on cold weather concreting (Kukko and Koskinen 1988). A section of that guide, devoted to antifreeze admixtures, provided a table of seven antifreeze admixtures with their low-temperature strengths. That table, shown as Table 1 in this report, lists the strengths of concrete maintained at the temperatures shown. This table, however, is only intended as a guide. RILEM recommends that concrete containing any antifreeze admixture be tested in the laboratory before being used in the field. Probably because of that caution, RILEM does not give mix proportions that would allow one to apply Table 1 directly in the field without first conducting laboratory experiments.

To get an idea of what antifreeze concentrations might be necessary to achieve the results shown in Table 1, Table 2 was developed from the literature. Data

Table 1. RILEM recommendations for cold weather concreting with antifreeze admixtures (after Kukko and Koskinen 1988).

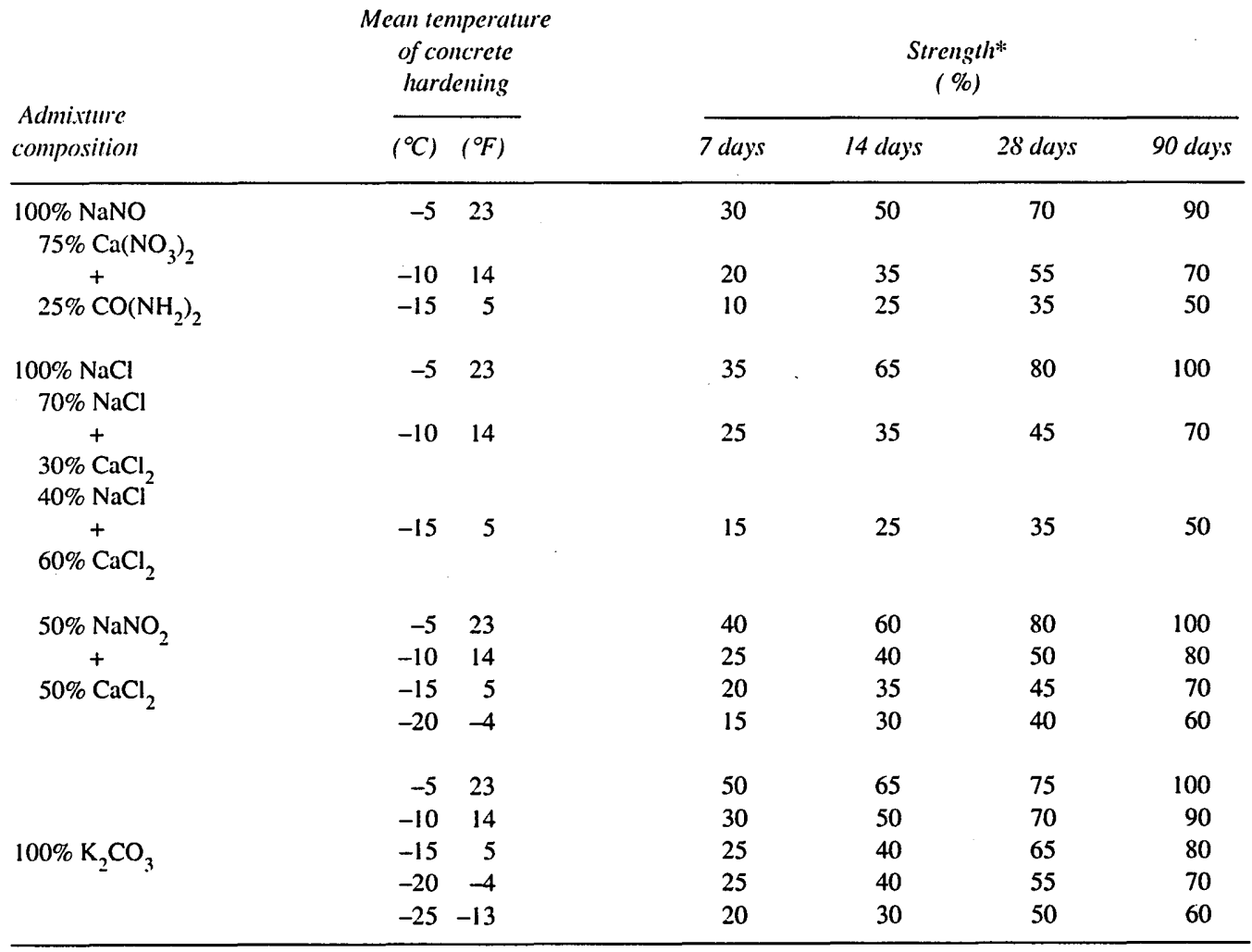

* Percent strength of control sample cured at room temperature for 28 days. 
Table 2. Common antifreeze admixtures for cold weather concreting.

\begin{tabular}{|c|c|c|c|c|c|}
\hline \multirow[b]{2}{*}{ Chemical } & \multirow{2}{*}{$\begin{array}{c}\text { Percent by } \\
\text { cement } \\
\text { weight }\end{array}$} & \multirow{2}{*}{$\begin{array}{l}\text { Strength* } \\
(\%)\end{array}$} & \multicolumn{2}{|c|}{ Temperature } & \multirow[b]{2}{*}{ Referencet } \\
\hline & & & $\left({ }^{\circ} \mathrm{C}\right)$ & $\left({ }^{\circ} \mathrm{F}\right)$ & \\
\hline $\mathrm{CaCl}_{2}$ & 7 : & 50 & -15 & 5 & $a, g, j, m, n, o, p, q, r$ \\
\hline $\mathrm{NaCl}^{2}$ & $5.7^{\circ}$ & 80 & -5 & 23 & $\mathrm{a}, \mathrm{b}, \mathrm{c}, \mathrm{j}, \mathrm{m}, \mathrm{n}, \mathrm{p}, \mathrm{q}$ \\
\hline \multirow{3}{*}{$\mathrm{NaNO}_{2}$} & 6 & 70 & -5 & 23 & a,d,e,s \\
\hline & 8 & 57 & -10 & 14 & $\mathrm{a}, \mathrm{d}, \mathrm{e}, \mathrm{s}$ \\
\hline & 10 & 36 & -20 & -4 & a,d,e,s \\
\hline $\mathrm{NaCl}+\mathrm{CaCl}_{2}$ & 7.7 & 58 & -20 & -4 & $\mathrm{~g}, \mathrm{~h}, \mathrm{n}, \mathrm{t}, \mathrm{u}, \mathrm{v}$ \\
\hline \multirow{4}{*}{$\mathrm{CaCl}_{2}+\mathrm{NaNO}_{2}$} & 5 & & -5 & 23 & b,c,e,h \\
\hline & 6.5 & & -10 & 14 & b,c,e,h \\
\hline & 8.5 & & -15 & 5 & b,c,e,h \\
\hline & 9 & 42 & -20 & -4 & b,c,e,h \\
\hline \multirow{4}{*}{$\mathrm{Ca}\left(\mathrm{NO}_{2}\right)_{2}+\mathrm{CO}\left(\mathrm{NH}_{2}\right)_{2}$} & 5.5 & & -5 & 23 & $b, c, f, k, l, w$ \\
\hline & 9.5 & 55 & -10 & 14 & $\mathrm{~b}, \mathrm{c}, \mathrm{f}, \mathrm{k}, \mathrm{l}, \mathrm{w}$ \\
\hline & 11 & 35 & -15 & 5 & $\mathrm{~b}, \mathrm{c}, \mathrm{f}, \mathrm{k}, \mathrm{l}, \mathrm{w}$ \\
\hline & 13 & & -20 & -4 & $\mathrm{~b}, \mathrm{c}, \mathrm{f}, \mathrm{k}, \mathrm{l}, \mathrm{w}$ \\
\hline \multirow{2}{*}{$\mathrm{Ca}\left(\mathrm{NO}_{3}\right)_{2}+\mathrm{CO}\left(\mathrm{NH}_{2}\right)_{2}$} & 8.8 & 29 & -10 & 14 & e,f,h,w \\
\hline & 9 & 34 & -20 & -4 & $e, f, h, w$ \\
\hline $\mathrm{Ca}\left(\mathrm{NO}_{3}\right)_{2}+\mathrm{Na}_{2} \mathrm{SO}_{4}$ & 6.6 & 56 & -10 & 14 & e,f,h,w \\
\hline \multirow{4}{*}{$\mathrm{Ca}\left(\mathrm{NO}_{2}\right)_{2} /\left(\mathrm{NO}_{3}\right)_{2}+\mathrm{CO}\left(\mathrm{NH}_{2}\right)_{2}$} & 5.5 & & -5 & 23 & b,c \\
\hline & 9.5 & & -10 & 14 & b,c \\
\hline & 11 & & -15 & 5 & b,c \\
\hline & 13 & & -20 & -4 & b,c \\
\hline \multirow{5}{*}[\mathrm{Ca}(\mathrm{NO}_{2})_{2}/(\mathrm{NO}_{3})_{2}+\mathrm{CaCl}_{2}]{$+\mathrm{CaCl}_{2}+\mathrm{NaNO}_{2}$} & 5 & & -5 & 23 & $\mathrm{~b}, \mathrm{c}$ \\
\hline & 9 & & -10 & 14 & b,c \\
\hline & 10 & & -15 & 5 & $b, c$ \\
\hline & 12 & & -20 & -4 & $b, c$ \\
\hline & 14 & & -25 & -13 & f,h,w \\
\hline \multirow[t]{4}{*}{$\mathrm{Ca}\left(\mathrm{NO}_{2}\right)_{2} /\left(\mathrm{NO}_{3}\right)_{2}+\mathrm{CaCl}_{2}+\mathrm{CO}\left(\mathrm{NH}_{2}\right)$} & 9 & 61 & -20 & -4 & $f, h, w$ \\
\hline & 11.5 & 40 & -20 & -4 & \\
\hline & 13 & & -20 & -4 & \\
\hline & 14 & & -25 & -13 & b,c \\
\hline \multirow[t]{5}{*}{$\mathrm{K}_{2} \mathrm{CO}_{3}$} & 6 & 75 & -5 & 23 & b,c,d \\
\hline & 8 & 70 & -10 & 14 & $b, c, f, i$ \\
\hline & 10 & 65 & -15 & 5 & $b, c, f, i$ \\
\hline & 10 & 47 & -20 & -4 & $b, c, f, i$ \\
\hline & 12 & 55 & -20 & -4 & $b, c, f, i$ \\
\hline $\mathrm{NaNO}_{2}+\mathrm{Na}_{2} \mathrm{SO}_{4}$ & 9 & 62 & -10 & 14 & d,e \\
\hline $\mathrm{NaNO}_{2}+\mathrm{Ca}\left(\mathrm{NO}_{3}\right)_{2}+\mathrm{CaCl}_{2}$ & 11.5 & 36 & -10 & 14 & $\mathrm{e}$ \\
\hline $\mathrm{NH}_{4} \mathrm{OH}$ & 5.2 & 93 & -20 & -4 & $x, y$ \\
\hline
\end{tabular}

* Percent strength of control sample cured at room temperature for 28 days.

†a-Mironov et al. (1976); b—Kukko and Koskinen (1988); c-Jokela et al. (1982); d—Low Temperature Building Sciences Institute (1979); e-Kivekas et al. (1985); f-Krylov et al. (1979); g-Mironov (1977); h-Goncharova and Ivanov (1975); i-Grapp et al. (1975); j-Kuzmin (1976); k-Virmani et al. (1983); l-Virmani (1988); m-Derrington (1967); n-Stormer (1970); o-Kostyayev et al. (1971); p—Yang (1982); q-Cottringer and Kendall (1923); r-Yates (1941); s-Mironov et al. (1979); t-Miettinen et al. (1981); u-Mironov and Krylov (1956); vSizov (1956); w-Golobov et al. (1974); x-Kuz'min et al. (1976); y-Bazhenov et al. (1974).

on strength, temperature and admixture concentration were selected from publications that most closely agreed with the strength and temperature data in Table 1. For those situations where strengths were not available, admixture concentrations and service temperatures were still provided to indicate potential ranges of use. Ad- mixtures that were not referenced by RILEM, but were commonly mentioned in the literature, were also included in Table 2. In addition, Table 2 lists helpful references on each admixture.

Jokela et al. (1982) group antifreezers by both their ability to depress freeze-points and to allow strength 
Table 3. Key to antifreeze chemicals.

\begin{tabular}{ll} 
Name & Symbol \\
\hline Ammonia & $\mathrm{NH}_{4} \mathrm{OH}$ \\
Calcium chloride & $\mathrm{CaCl}_{2}$ \\
Calcium nitrate & $\mathrm{Ca}\left(\mathrm{NO}_{3}\right)_{2}$ \\
Calcium nitrite & $\mathrm{Ca}\left(\mathrm{NO}_{2}\right)_{2}$ \\
Sodium chloride & $\mathrm{NaCl}$ \\
Sodium nitrate & $\mathrm{NaNO}_{3}$ \\
Sodium nitrite & $\mathrm{NaNO}_{2}$ \\
Sodium sulfate & $\mathrm{Na}_{2} \mathrm{SO}_{4}$ \\
Potash & $\mathrm{K}_{2} \mathrm{CO}_{3}$ \\
Urea & $\mathrm{CO}\left(\mathrm{NH}_{2}\right)_{2}$ \\
\hline
\end{tabular}

gain at low temperature. The first group consists of sodium chloride, sodium nitrite and urea. The second group consists of calcium chloride, calcium nitrite and potassium carbonate. Accelerators usually must be added to the group one antifreezers, while group two can be used alone.

Table 3 provides a key to identify the antifreeze admixtures mentioned in this report.

\section{EFFECTS OF ANTIFREEZE ADMIXTURES ON CONCRETE}

As with any additive, there is concern over antifreeze admixtures' effects on concrete properties. The effect that they have on concrete with respect to compressive strength, tensile strength, frost durability, aggregate reaction, corrosion of embedded metal and the formation of ice are presented below. In many instances the information uncovered was qualitative rather than quantitative.

\section{Compressive strength}

A common indicator of concrete quality is compressive strength. Safe and economical scheduling of crucial construction operations makes it important that concrete attain certain strengths before work progresses. It is critical that concrete reach $3.4 \mathrm{MPa}\left(500 \mathrm{lb} / \mathrm{in}^{2}{ }^{2}\right)$ before being exposed to one freeze-thaw cycle and 24 MPa ( $\left.3500 \mathrm{lb} / \mathrm{in}^{2}{ }^{2}\right)$ for multiple freeze-thaw cycles (ACI 1988). Formwork is not safely removed until the concrete becomes strong enough to support itself and any imposed construction load; a structure is not fully serviceable unless the design strength is achieved. Thus, the effect that antifreezers have on both the rate of strength gain and the ultimate strength of concrete is important.

Compressive strengths are shown in Tables 1 and 2.
As can be seen, the rate of strength development for low-temperature concrete made with antifreeze admixtures lags that of similar room-temperature concrete made without admixtures. This strength lag varies with admixture and with temperature. For example, strength gains range from a high of $93 \%$ of the 28-day strength of control samples for ammonia at $-20^{\circ} \mathrm{C}\left(-4^{\circ} \mathrm{F}\right)$ to a low of $29 \%$ for calcium nitrate plus urea at $-10^{\circ} \mathrm{C}$ $\left(14^{\circ} \mathrm{F}\right)$.

The design strength of concrete is commonly the 28day compressive strength. It is important to note that strength gain of antifreeze concrete at low temperature does not stop at 28 days. Normal concrete also gains strength after 28 days but at a much slower rate. Table 1 goes on to show that after 90 days of low-temperature curing, strength continues to improve to where, with some admixtures, it eventually approaches that of the 28-day design strength. Three of the seven admixture combinations in Table 1 reached $100 \%$ of design strength after 90 days of low-temperature curing. Even the slowest curing admixture, sodium-calcium chloride at $-15^{\circ} \mathrm{C}\left(-5^{\circ} \mathrm{F}\right)$, achieved $50 \%$ of design strength in 90 days. If cured for longer than 90 days, indications are that antifreeze concrete will gain its full expected design strength, and then some. In tests conducted for as long as 1-1/2 years, the Low Temperature Building Sciences Institute of China (1979) showed that concrete made with sodium nitrite plus sodium sulfate gained $114 \%$ of 28-day design strength (Fig. 1).

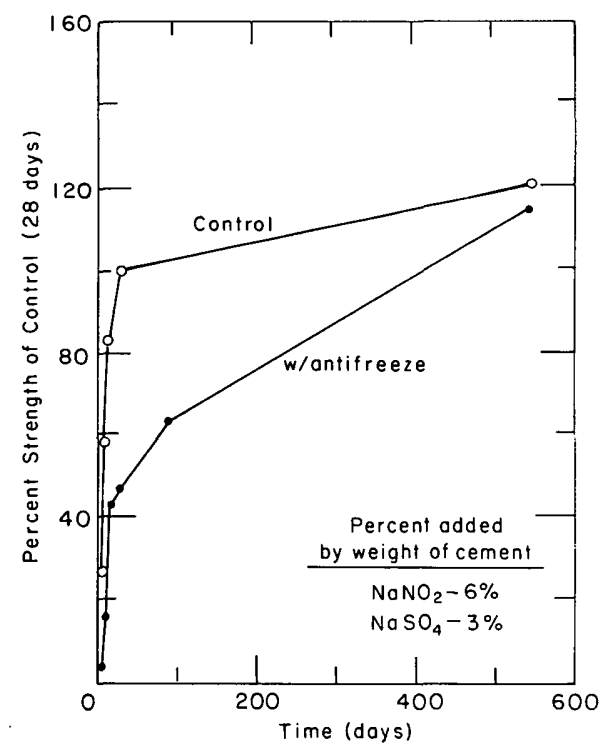

Figure 1. Comparison of long-term strengths between normal concrete at room temperature and sodium nitrite/sodium sulfate concrete at $-10^{\circ} \mathrm{C}$ (after Low Temperature Building Sciences Institute 1979). 


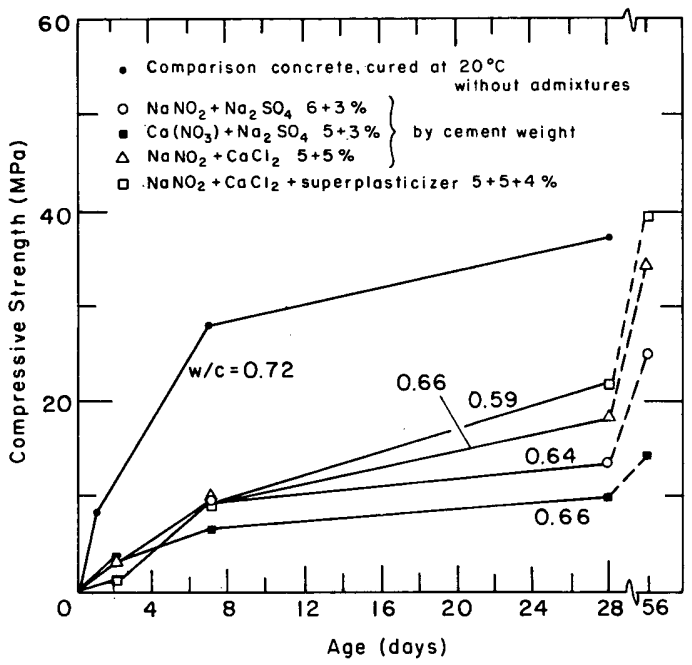

Figure 2. Compressive strengths of antifieeze-concrete at $-10^{\circ} \mathrm{C}$ compared to normal concrete at $20^{\circ} \mathrm{C}$. The dashed lines indicate room-temperature curing (after Kivekas et al. 1985).

In practice, when air temperatures rise, concrete strength gain should accelerate. Kivekas et al. (1985) provide an example of this temperature effect. In Figure 2 they show the typical early age strength lag for a variety of admixtures cured at low temperature; however, when the admixtures are cured at room temperature for an additional period, strengths show a marked improvement. Further, when the water-cement ratio $(w / c)$ of the sodium nitrite plus calcium chloride concrete mix was reduced to 0.59 from 0.66 by including a water reducer, compressive strength improved. This has practical implications as concrete placed in the winter cannot only be expected to slowly gain strength but can be expected to gain appreciable strength the ensuing spring and summer, provided, of course, that proper moisture conditions are maintained.

Another important strength question concerns the minimum or critical strength that concrete must attain before freezing. Krylov et al. (1979) felt that the mini- mum strengths needed before freezing depend on the cement type, the admixture type, the mix design strength and the rate of cooling. The strength before freezing of normal concrete in the U.S.S.R. is $5 \mathrm{MPa}\left(725 \mathrm{lb} / \mathrm{in} .{ }^{2}\right)$ and this can, according to Krylov et al., be reduced by a factor of up to 2 when antifreeze admixtures are used. It is not clear why they make this recommendation, unless they assume that not all of the mix water freezes, even at very low temperatures. However, it suggests that little curing is required before a concrete made with antifreeze admixtures is allowed to freeze.

Compressive strength, as well as other structural properties of concrete, depends on the degree to which cement hydrates. According to Mironov (1977), hydration can be increased by introducing antifreeze admixtures into the concrete. Table 4 shows the effect of sodium nitrite and potash on the degree of hydration of portland cement. As Table 4 shows, potash slows cement hydration at room temperature, has essentially no effect on it at $0^{\circ} \mathrm{C}\left(32^{\circ} \mathrm{F}\right)$ and accelerates hydration at $-10(14)$ and $-20^{\circ} \mathrm{C}\left(-4^{\circ} \mathrm{F}\right)$ compared to normal cement at those temperatures. Sodium nitrite, on the other hand, is moderately effective at temperatures down to $0^{\circ} \mathrm{C}$. At -10 and $-20^{\circ} \mathrm{C}$ it accelerates hydration but not to the same degree as does the potash. It is interesting to note that sodium nitrite remained effective at low temperatures even at concentrations of $2 \%$. In comparison, Table 2 shows that in practice a $6-10 \%$ sodium nitrite concentration is used.

\section{Tensile strength}

Another important design parameter is the tensile strength of concrete. It is particularly important for pavements. Higher tensile strengths produce higher flexural strengths and therefore reduce the necessary thickness. Tensile strength is also important in determining how well concrete withstands frost. Those concretes with high tensile strengths are better able to resist the expansive stresses that arise in the process of ice formation. Unfortunately, very little is published on this concrete property.

In the little that is published, Goncharova and Ivanov

Table 4. Hydration of cement at 28 days (after Mironov 1977).

\begin{tabular}{lccccc} 
& $\begin{array}{c}\text { Admixture } \\
\% \text { by } \\
\text { cement }\end{array}$ & \multicolumn{4}{c}{ Percent hydration at } \\
\cline { 3 - 6 } Antifreezer & weight & $\begin{array}{c}20^{\circ} \mathrm{C} \\
\left(70^{\circ} \mathrm{F}\right)\end{array}$ & $\begin{array}{c}0^{\circ} \mathrm{C} \\
\left(32^{\circ} \mathrm{F}\right)\end{array}$ & $\begin{array}{c}-10^{\circ} \mathrm{C} \\
\left(14^{\circ} \mathrm{F}\right)\end{array}$ & $\begin{array}{c}-20^{\circ} \mathrm{C} \\
\left(-4{ }^{\circ} \mathrm{F}\right)\end{array}$ \\
\hline $\mathrm{Control}$ & none & 66 & 39 & 20 & 1 \\
$\mathrm{NaNO}_{2}$ & 2 & 64 & 44 & 43 & 17 \\
$\mathrm{NaNO}_{2}$ & 10 & 67 & 43 & 42 & 27 \\
$\mathrm{~K}_{2} \mathrm{CO}_{3}$ & 10 & 55 & 41 & 46 & 37 \\
\hline
\end{tabular}


(1975) state that tensile, compressive and cohesive strengths are "on average the same as those of additivefree concrete hardened under normal humidity conditions," while Grapp et al. (1975) show that the engineering properties of concrete were affected by potash, the one admixture they tested. According to Grapp et al., there is a measured decrease in the dynamic modulus of elasticity, an increase in the coefficient of expansion and a decrease in the split-tensile strength of concrete containing potash. This coincides with the low freeze-thaw durability of potash concrete reported next.

\section{Freeze-thaw durability}

Freeze-thaw durability of concrete, a critical factor in the cold regions, is discussed by Goncharova and Ivanov (1975), Grapp et al. (1975) and Kuzmin (1976), who looked at the effect of antifreeze admixtures. A summary of their findings is presented in Figures 3 and 4.

Goncharova and Ivanov studied the admixtures shown in Figure 3 by first curing $4-\times 4-\times 16-\mathrm{cm}(1.5-\times 1.5-$ $\times 6$-in.) specimens at $-20^{\circ} \mathrm{C}\left(-4^{\circ} \mathrm{F}\right)$ for 28 days, followed by an additional curing period of 28 days at room

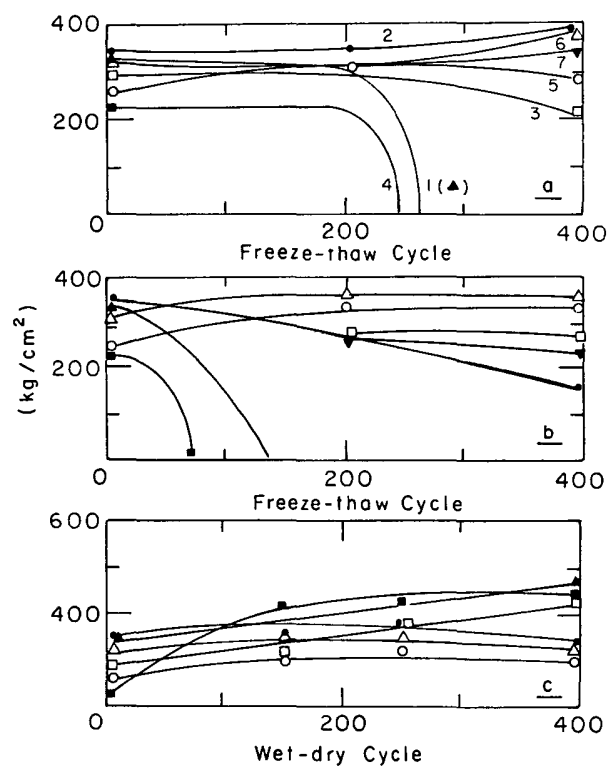

Figure 3.Durability tests of concrete at a water-cement ratio of 0.45 . The admixtures are given as percent by cement weight (after Goncharova and Ivanov 1975). 1-Control without air-entraining admixture; $2-\mathrm{CaCl}_{2}+$ $\mathrm{NaCl}(8.5 \%) ; 3-\mathrm{NaNO}_{2}(10 \%) ; 4-\mathrm{K}_{2} \mathrm{CO}_{3}(10 \%) ; 5-$ $\mathrm{Ca}\left(\mathrm{NO}_{3}\right)_{2}+\mathrm{CO}\left(\mathrm{NH}_{2}\right)_{2}(9 \%) ; 6-\mathrm{Ca}\left(\mathrm{NO}_{3}\right)_{2}\left(\mathrm{NO}_{2}\right)_{2}+\mathrm{CaCl}_{2}+$ $\mathrm{CO}\left(\mathrm{NH}_{2}\right)_{2}(9 \%) ; 7-\mathrm{CaCl}_{2}+\mathrm{NaNO}_{2}(9 \%)$. a-Compressive strength when frozen in air and thawed in fresh water. $b-$ Same as a above except thaw water contains $5 \% \mathrm{NaCl}$. CCompressive strength when wet-dry cycled at $60^{\circ} \mathrm{C}$.

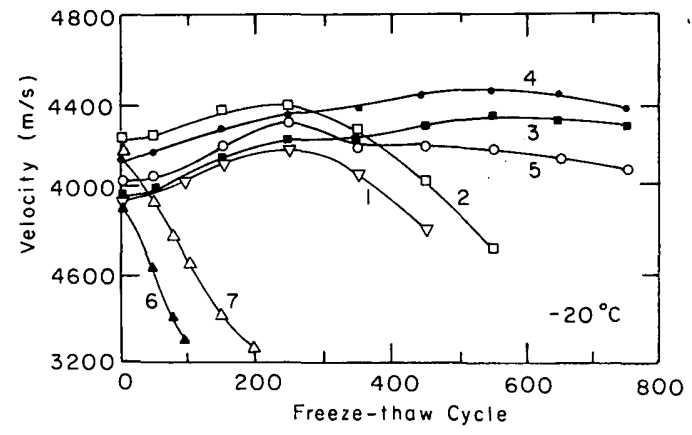

Figure 4. Durability of concrete with admixture concentrations given as percent by cement weight (water-cement ratio of 3:1) (after Grapp et al. 1975). $1-$ Control without air-entraining admixture; $2-15 \% \mathrm{NaNO}_{2}$; $3-15 \% \mathrm{Ca}\left(\mathrm{NO}_{3}\right)_{2}+\mathrm{CO}\left(\mathrm{NH}_{2}\right)_{2} ; 4-15 \% \mathrm{Ca}\left(\mathrm{NO}_{3}\right)_{2} /\left(\mathrm{NO}_{2}\right)_{2}+$ $\mathrm{CaCl}_{2}+\mathrm{CO}\left(\mathrm{NH}_{2}\right)_{2} ; 5-15 \% \mathrm{NaNO}_{2}+\mathrm{CaCl}_{2} ; 6-15 \% \mathrm{~K}_{2} \mathrm{CO}_{3}$; $7-25 \% \mathrm{~K}_{2} \mathrm{CO}_{3}$.

temperature. The specimens were cast from ingredients that were cooled to $-5^{\circ} \mathrm{C}\left(23^{\circ} \mathrm{F}\right)$. Once cured, the specimens were subjected to alternate cycles of freezing in air and thawing in water. The freeze-thaw temperature range is not known, but ten freeze-thaw cycles were completed each week. The performance of concretes made with antifreeze admixtures was compared to that of non-air-entrained concrete cured at standard conditions and subjected to the same freeze-thaw cycling. They evaluated concrete performance by monitoring the change in compressive strength, the change in weight and the change in length of each specimen. For this discussion, only the change in strength will be shown, as the other two test parameters reflect the same trend as seen in the strength change. Figure 3 a shows that, except for potash, all admixtures tested increased the freeze-thaw durability of concrete compared to non-air-entrained concrete without additives. Potash and non-air-entrained concrete began to lose strength by the 200th cycle. ASTM (1984) publication C666 says that durable concrete should be relatively unaffected by 300 cycles of freezing and thawing. Based on that guidance, all admixtures, but potash, appear to produce durable concrete, even without using an air-entraining agent.

Goncharova and Ivanov conducted two other durability tests that deserve mention here. In one test, instead of using fresh water to thaw concrete samples, they used a $5 \%$ sodium chloride solution as the thaw water. They used curing and test conditions identical to those discussed above. The significance with this test method is that strength was lost sooner (Fig. 3b), compared to what happened when fresh water was used. Again, all additives but potash improved durability over that of the 
control concrete. Perhaps sodium chloride solutions should be investigated as an alternative thaw medium for speeding up freeze-thaw tests.

In their third durability test, Goncharova and Ivanov did not freeze the concrete during testing but, instead, repeatedly wet and dried samples at $60^{\circ} \mathrm{C}\left(140^{\circ} \mathrm{F}\right)$. Figure $3 \mathrm{c}$ shows less of a performance difference among the concretes than did the two freeze-thaw tests. However, a close look at Figure $3 \mathrm{c}$ reveals that calcium chloride plus sodium chloride, calcium nitrate plus urea, and calcium nitrite-nitrate plus calcium chloride plus urea lost strength sooner than did the control sample or the potash. Goncharova and Ivanov suggest that wet-dry cycling at elevated temperatures might be useful to evaluate the long-term effect of the salt crystals that remain in the concrete.

Grappet al. (1975) used a method similar to Goncharova and Ivanov's first method to study freeze-thaw durability. Their testing differed from Goncharova and Ivanov's in that two freezing temperatures of $-20(-4)$ and $-60^{\circ} \mathrm{C}\left(-76^{\circ} \mathrm{F}\right)$ were used and durability was monitored with ultrasound waves and flexural strength tests. Mixing temperatures were not given. Like Goncharova and Ivanov, Grapp et al. found potash to be the only admixture to reduce freeze-thaw resistance of concrete. This can be seen as a sharp drop in velocity readings in Figure 4. Though not shown in Figure 4, Grapp et al. indicated that lowering the test temperature to $-60^{\circ} \mathrm{C}$ did not change the results. They saw no advantage to using lower temperatures as a way to speed up freeze-thaw testing.

Kuzmin (1976) discussed the results of tests examining concrete durability that accounted for the partial formation of ice in early age concrete. His freeze-thaw testing was similar to Goncharova and Ivanov's first method. In general, Kuzmin indicates that ice formed before concrete is fully hardened can have a positive or a negative effect, depending on the admixture and the amount of ice. For fresh concrete containing $10 \%$ calcium chloride and $5 \%$ sodium chloride, $52 \%$ of the mix water turned to ice at $-18^{\circ} \mathrm{C}\left(0^{\circ} \mathrm{F}\right)$. Using $5 \%$ of each salt increased the ice to $78 \%$. According to Kuzmin, both of these early age ice amounts had an adverse effect on the ultimate freeze-thaw durability of concrete. (That's somewhat contradictory to the allowed ice contents mentioned later in this report.)

In tests of fresh concretes containing 7 and $10 \%$ ammonia (by cement weight) as the antifreeze, 25 to $30 \%$ of the initial weight of mix water turned to ice at $-12(10)$ and $-20^{\circ} \mathrm{C}\left(-4^{\circ} \mathrm{F}\right)$, respectively, without ultimate harm to the concrete. In fact, Kuzmin indicates that this amount of ice increased both the long-term compressive strength and freeze-thaw durability of concrete. He did not indicate, however, if these lower ice contents would have the same beneficial effect on the above mentioned sodium-calcium chloride concretes.

Air-entraining admixtures are commonly used to improve the freeze-thaw durability of normal concrete. Both Grapp et al. and Kuzmin indicate that using such admixtures should improve the freeze-thaw resistance of antifreeze concrete, but neither conducted tests to prove that. The concern is whether antifreeze admixtures would upset the bubble-stabilizing capacity of the air-entraining admixtures.

This concern manifests in a field study conducted by Korhonen (1987), where she got mixed results when she tried to add air-entraining admixtures to three commercial antifreeze admixtures. She found it difficult to find an air-entraining admixture that would produce stable air contents, particularly with one antifreeze admixture (the chemical makeup of the antifreezers was not revealed). Laboratory tests showed reasonable results but, in transporting the mix from the readymix plant to the job site, air contents changed. In some cases the air content increased and in other cases the air content decreased. Nevertheless, adjustments were made and measurements at the job site indicated the correct air content. But, when the forms were removed, she discovered that air bubbles had clustered in various locations on the surface of the concrete. This casts some doubt on the compatibility of antifreeze admixtures and air-entraining admixtures.

\section{Reaction with aggregate}

Over the past several decades, awareness of chemical reactions between aggregate and cement paste has been heightened. A common reaction takes place between silica in the aggregate and alkalies in the cement. If there is a chance that aggregate may be reactive, the common solution is to use low-alkali cement.

Mironov et al. (1976) reported that sodium nitrite and potash form caustic alkalies when they react with cement; therefore, they should not be used with reactive silica aggregate. What's more, concrete made with these additives is weakened by repeated changes in moisture. So, beside being restricted by the aggregate type, these additives should not be used in a marine environment.

\section{Corrosion of embedded steel}

Under normal circumstances, cement provides an alkaline environment that protects steel from corrosion. Anything that neutralizes this alkalinity renders steel vulnerable to corrosion in the presence of moisture and oxygen. Carbon dioxide and chloride are two common sources that initiate corrosion of embedded steel.

Several references spoke of the effects of antifreeze 
Table 5. Corrosion of embedded steel and antifreeze admixtures.

\begin{tabular}{lll} 
Antifieczer & \multicolumn{1}{c}{ Corrosion } & Reference* \\
\hline $\mathrm{NaNO}_{3}$ & no corrosion & a \\
$\mathrm{NH}_{4} \mathrm{OH}$ & no corrosion & b \\
$\mathrm{Ca}\left(\mathrm{NO}_{3}\right)_{2}$ & no corrosion & $\mathrm{c}$ \\
$\mathrm{K}_{2} \mathrm{CO}_{3}$ & no corrosion & $\mathrm{c}$ \\
$\mathrm{NaSO}_{4}$ & no corrosion & c \\
$\mathrm{Ca}\left(\mathrm{NO}_{3}\right)_{2}+\mathrm{CO}\left(\mathrm{NH}_{2}\right)_{2}$ & no corrosion & c \\
$\mathrm{Ca}\left(\mathrm{NO}_{2}\right)_{2}$ & inhibitor & $\mathrm{c}$ \\
$\mathrm{NaNO}$ & inhibitor & c,d \\
$\mathrm{NaOH}$ & inhibitor & e \\
$\mathrm{NaCl}$ & causes corrosion & c \\
$\mathrm{CaCl}$ & causes corrosion & c \\
\hline
\end{tabular}

*a—Mironov et al. (1979); b-Kuz'min et al. (1976); c-Kuzmin (1976); d-Sheikin et al. (1980); e—Ovcharov (1972).

admixtures on the corrosion of steel-conclusions are summarized in Table 5. Calcium chloride and sodium chloride were identified as corrosion causers. The Low Temperature Building Sciences Institute of China (1979) indicates that, although sodium nitrite inhibits corrosion, it does so only if at least $4.4 \%$ sodium nitrite by cement weight is used in the cement mix. Otherwise, local rusting can occur, which is more dangerous than overall rusting because it is difficult to detect. When one area is attacked, strength is lost quicker than if the whole rebar were attacked equally. The $4.4 \%$ sodium nitrite also neutralizes the effects of sodium chloride, which may be applied as part of an ice control program. Virmani et al. (1988) and Virmani (1983) found that calcium nitrite also neutralized the effects of chloride ions.

\section{Formation of ice in fresh concrete}

The main function of an antifreeze admixture is to prevent water from freezing so that it can react with cement at low temperature. The effectiveness of an antifreeze for reducing the freezing point of water is related to its eutectic point, i.e., the lowest temperature below which additional quantities of antifreeze will not depress the freezing point further. Table 6 gives eutectic point properties for individual chemicals. As can be seen, ammonia, calcium chloride and potash are among the best in freeze protection.

The effectiveness of an antifreeze admixture when placed in a concrete mix is based on the amount of antifreeze used. If eutectic concentrations are used, no ice will form in the mix water until the eutectic temperature is reached. However, the eutectic concentration is not the admixture concentration recommended in published literature. Generally, a solute concentration corresponding to a temperature several degrees above the eutectic temperature is recommended. Because less than the eutectic concentration is used, some ice usually forms in the concrete while it cures.

Ice is not usually thought of as a desired component in fresh concrete-Mironov (1977) shows why. Figure 5 shows the amount of mix water that freezes in normal concrete of various ages. When frozen immediately after mixing, over $90 \%$ of the mix water turns into ice at $-3^{\circ} \mathrm{C}\left(27^{\circ} \mathrm{F}\right)$. At this point the concrete has not set, very little liquid water remains, the hydration is severely retarded and will stop once the liquid water is used up, and the overall volume of the concrete has increased. Unless the concrete is reconsolidated before setting takes place, the resulting concrete will be very porous and weak, even if it cures after the ice thaws. After 1 day of room-temperature curing, less water is available for freezing because of the increased hydration of the cement and also because some water has been confined in the pores where it is more difficult to freeze. Eventu-

Table 6. Approximate eutectic temperatures.

\begin{tabular}{lcc} 
Chemical & $\begin{array}{c}\text { Percent } \\
\text { solution }\end{array}$ & $\begin{array}{c}\text { Temip. } \\
\left({ }^{\circ} \mathrm{C}\right)\end{array}$ \\
\hline $\mathrm{NH}_{4} \mathrm{OH}$ & 61 & -84 \\
$\mathrm{CaCl}_{2}$ & 30 & -55 \\
$\mathrm{~K}_{2} \mathrm{CO}_{3}$ & 40 & -37 \\
$\mathrm{NaCl}$ & 23 & -21 \\
$\mathrm{NaNO}$ & 28 & -20 \\
$\mathrm{Ca}\left(\mathrm{NO}_{2}\right)_{2}$ & 34 & -20 \\
$\mathrm{CO}\left(\mathrm{NH}_{2}\right)_{2}$ & 44 & -18 \\
$\mathrm{Ca}\left(\mathrm{NO}_{3}\right)_{2}$ & 35 & -16 \\
$\mathrm{Na}_{2} \mathrm{SO}_{4}$ & 13 & -4 \\
\hline
\end{tabular}




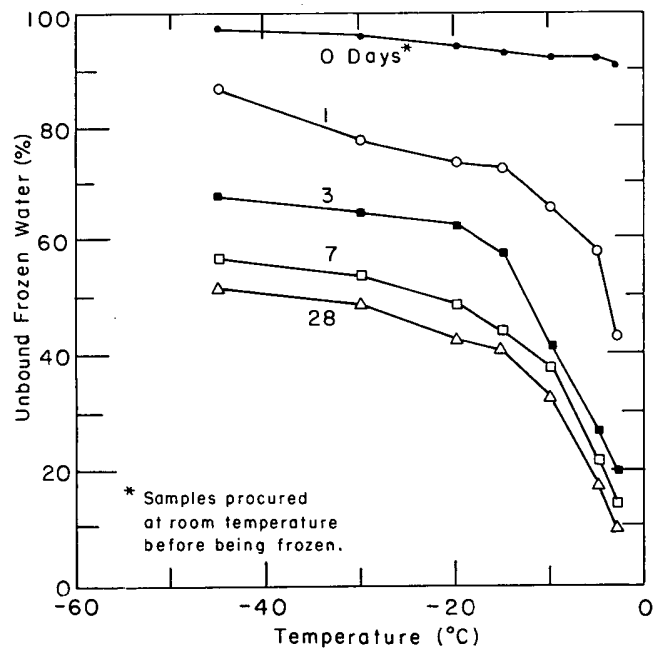

Figure 5. Initial ice content of additive-fiee concrete at various strengths (after Mironov 1977).

ally, the quantity of ice that can be produced is reduced to where freezing temperatures will not harm the concrete.

An interesting finding of Mironov, though not shown in Figure 5, is that up to $20 \%$ of the mix water can turn to ice and not harm the ultimate strength of the concrete. He found that, when freshly mixed concrete was rapidly cooled to $-1^{\circ} \mathrm{C}$ and cured at that temperature, its 28-day strength reached $70 \%$ of that of similar concrete cured at room temperature. Thus, if this amount of ice can be tolerated in normal concrete, then the task of an antifreeze admixture becomes one of only minimizing and not necessarily eliminating ice from curing concrete.

Kuzmin (1976) demonstrated the effect of ice on the ultimate strength of antifreeze concrete when the concrete was rapidly frozen after mixing. The concrete was kept at $-10^{\circ} \mathrm{C}$ until it developed the desired ice content of 20,40 or $60 \%$. Then the concrete was changed to room temperature and cured for 28 days. As Figure 6 shows, concrete made with potash, sodium nitrite or ammonia gained in compressive strength with each increase in ice content up to $40 \%$-then strengths dropped sharply. Kuzmin (1976) provides two explanations for the strength increases:

1. Only some of the water freezes, which limits the harmful effects of expansion as water turns to ice.

2. The ice that forms compacts the cement gel rather than disrupts it.

The literature differed on the amount of ice that could be allowed in fresh concrete. For example, RILEM (Kukko and Koskinen 1988) indicates that 40 to $60 \%$ is a permissible range of ice contents for fresh concrete. In an earlier section of this report, a $52 \%$ ice content was shown to be detrimental to concrete made with sodium-calcium chlorides, while up to $30 \%$ ice improved the ultimate strength and freeze-thaw clurability of concretes made with ammonia.

Besides the amount of ice that forms, the location within the cơncrete where it forms may also be critical. The rate of cooling plays an important role in determining the location and type of ice that forms-uniform small crystals or ice lenses. Either type of ice may damage the concrete. Krylov et al. (1979) suggest that slow cooling may be of more concern than rapid cooling in some instances. In their tests, concrete placed in $-25^{\circ} \mathrm{C}\left(-13^{\circ} \mathrm{F}\right)$ cabinets lost more strength than similar concrete placed in $-40^{\circ} \mathrm{C}\left(-40^{\circ} \mathrm{F}\right)$ cabinets. According to Krylov et al., the difference in strength at these two temperatures is ascribable to the difference in potential for moisture migration within the concrete. At slow cooling rates $\left(-25^{\circ} \mathrm{C}\right)$ moisture migration is more pronounced than at rapid freezing $\left(-40^{\circ} \mathrm{C}\right)$. When concrete is cooled slowly, moisture has time to migrate toward the cold surface where it can form an ice lens that disrupts the concrete. On the other hand, if cooling is rapid, the water freezes in place, possibly causing less disruption to the concrete.

Since ice formation is normal in low-temperature curing of antifreeze concrete, the effect of ice formation in massive structures, where moisture migration and ice lenses are likely, needs investigation.

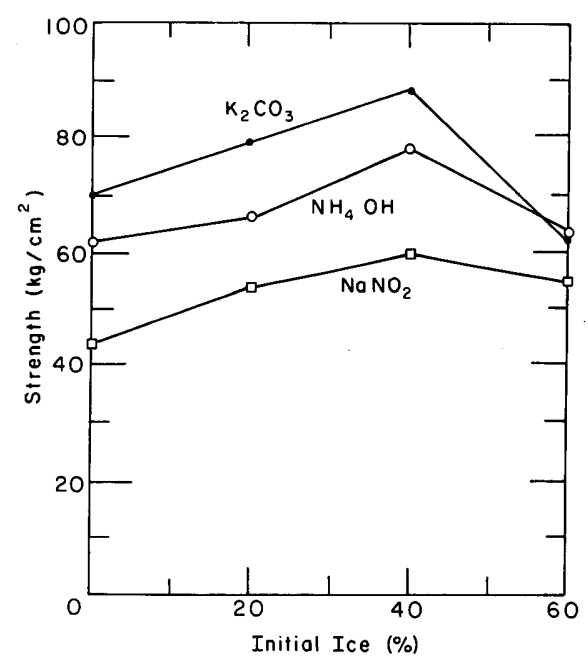

Figure 6. Strength vs initial ice content. Concrete was cured at $-10^{\circ} \mathrm{C}$ until the desired ice content was achieved, then it was cured at room temperature for 28 days. The ice started to form within 20 minutes of being placed in the $-10^{\circ} \mathrm{C}$ cabinet (after Kuzmin 1976). 


\section{MIXING OF ANTIFREEZE CONCRETE}

Antifreeze concrete is mixed in much the same manner as is normal concrete. Usually, the concrete is mixed at a ready-mix plant at room temperature (some laboratory tests were done with ingredients cooled ahead of time, as mentioned earlier). The antifreeze is added to the water, which is then added to the mix. The concrete is transported by conventional, uninsulated rotating-drum trucks. The concrete is not allowed to freeze before it reaches the site and the forms must be free of ice and snow. Open surfaces are covered with plastic and insulated if the air temperature falls below the lowest recommended curing temperature. In extreme cold, heat can be applied, but then the advantage of the antifreeze is diminished as costs increase. If the concrete has attained critical strength, nothing need be done to protect the concrete.

A variation on this practice, one employed by a Finnish ready-mix company, has the truck driver place bags of antifreeze into the empty drum of the mixing truck. The truck is then charged with ready-mix concrete and driven to the job site. Because the bags containing the antifreeze dissolve in the truck, a 3minute drum rotation at the site readies the concrete for use. This practice is especially good for potash, which has a tendency to set up rapidly.

A major advantage of working in the cold is that concrete can be hauled long distances before hardening. Kuzmin (1976) lists permissible haul times in Table 7sodium nitrite and ammonia can be hauled for long times before setting, whereas concrete containing potash sets quicker than normal concrete at room temperature, so must be placed within $1 / 2$ hour of mixing.

Korhonen (1987) described a field test in which concrete containing sodium nitrite and potash as the principal ingredients was hauled $7-1 / 2$ hours in mix trucks at air temperatures of -5 to $-10^{\circ} \mathrm{C}\left(23\right.$ to $\left.14^{\circ} \mathrm{F}\right)$. One mix stiffened (probably the potash) and had to be remixed with additional water but none lost strength. Jokela et al. (1982) indicate that concrete made with urea is also good for long distance hauling.

\section{STANDARDS}

As previously mentioned, cold weather concreting practices in the U.S. are based primarily on the guidance provided by the American Concrete Institute (ACI 1988). Antifreeze admixtures are not currently included as a cold weather concreting option in that report, although consideration is being given to including their mention in a future update. ACI-212 (ACI 1985) specifically prohibits antifreeze admixtures. Section
Table 7.Permissible haul times (after Kuzmin 1976).

\begin{tabular}{|c|c|c|c|c|}
\hline \multicolumn{2}{|c|}{ Temp. } & \multicolumn{2}{|r|}{$\begin{array}{l}\text { Percent } \\
\text { by weight }\end{array}$} & \multirow{2}{*}{$\begin{array}{c}\text { Haul } \\
\text { time } \\
\text { (hours) }\end{array}$} \\
\hline$\left({ }^{\circ} \mathrm{C}\right)$ & $\left({ }^{\circ} F\right)$ & Admixture & water & \\
\hline 20 & 20 & none & - & $2-3$ \\
\hline \multirow[t]{3}{*}{-5} & 23 & $\mathrm{~K}_{2} \mathrm{CO}_{3}$ & 14 & $1 / 2$ \\
\hline & & $\mathrm{NH}_{4} \mathrm{OH}$ & 5 & $8-9$ \\
\hline & & $\mathrm{NaNO}_{2}$ & 12 & $8-9$ \\
\hline \multirow[t]{3}{*}{-10} & 14 & $\mathrm{~K}_{2} \mathrm{CO}_{3}^{2}$ & 22 & $1 / 2$ \\
\hline & & $\mathrm{NH}_{4} \mathrm{OH}$ & 9 & $9-10$ \\
\hline & & $\mathrm{NaNO}_{2}$ & 19 & $9-10$ \\
\hline \multirow[t]{3}{*}{-15} & 5 & $\mathrm{~K}_{2} \mathrm{CO}_{3}^{2}$ & 27 & $1 / 2$ \\
\hline & & $\mathrm{NH}_{4} \mathrm{OH}$ & 12 & $9-10$ \\
\hline & & $\mathrm{NaNO}_{2}$ & 25 & $9-10$ \\
\hline \multirow[t]{3}{*}{-20} & -4 & $\mathrm{~K}_{2} \mathrm{CO}_{3}{ }^{2}$ & 32 & $1 / 2$ \\
\hline & & $\mathrm{NH}_{4} \mathrm{OH}$ & 15 & $14-15$ \\
\hline & & $\mathrm{NaNO}_{2}$ & 18 & $24-30$ \\
\hline
\end{tabular}

3.2.2 of that report states, "No materials are known which will substantially lower the freezing point of the water in concrete without being harmful to the concrete in other respects (p. 212.1R-7)." As just mentioned, $\mathrm{ACI}$ is interested in an update that includes more recent information on antifreeze admixtures.

Beginning in 1976, RILEM made a concerted effort to collect the experiences of various countries with winter concreting. The Technical Research Center of Finland (VTT), Concrete and Silicate Laboratory, summarized these findings in 1988 (Kukko and Koskinen 1988). The VTT report addresses approaches to winter concreting, including the use of antifreeze admixtures. As evidenced in the report, cold weather concreting receives priority treatment in the northern European countries.

\section{COST EFFECTIVENESS OF ANTIFREEZE ADMIXTURES}

Winter increases construction costs. Much of this increase is caused by a drop in the efficiency of construction machinery and manual labor. Jokela et al. (1982) note that machinery costs increase 1.6 to 2 times and manual labor takes about twice as long when work is done in cold weather. Some estimates have placed winter construction costs even higher.

According to Mironov and Demidov (1978), winter conditions can increase concreting costs by a factor of 1.5-2. High heating requirements and the need for protection account for much of this increase. When using concretes containing antifreeze admixtures, however, the need for special protection diminishes, 
and any increased costs associated with the antifreeze admixtures are offset by the reduced winter protection requirements. Kuzmin (1976) says that up to $94 \%$ of the added cost of using antifreeze admixtures is attributable to the cost of the admixture itself. The remaining $6 \%$ is associated with processing and handling the admixture. Therefore, the cost effectiveness of antifreeze admixtures can be reasonably estimated on the basis of admixture costs.

To get a feel for the costs of antifreezers, various ready-mix producers and chemical companies were contacted for prices. Table 8 presents the added cost per cubic yard of concrete if the admixtures are purchased in bulk quantity. Considering that ready-mix concrete (six-bag mix) costs $\$ 61.75 / \mathrm{yd}^{3}\left(\$ 80.77 / \mathrm{m}^{3}\right.$ ) in Boston (ENR 1989) and that placing and protecting that cubic yard in the winter might cost another $\$ 30-60$ (1.5-2 factor), it can be seen that the Table 8 costs are competitive with normal winter concreting practices. It should be kept in mind, however, that these prices do not represent end-user prices. Handling and profit would increase the price for antifreeze concrete somewhat.

As an idea of how much antifreezers might ultimately cost, one company in Finland increases its normal ready-mix price by $75 \%$ when antifreeze admixtures are used. It is not known what chemicals or how

Table 8. Added cost per cubic yard of concrete for antifreeze admixture.

\begin{tabular}{|c|c|c|c|c|c|}
\hline \multirow[b]{2}{*}{ Chemical } & \multirow[b]{2}{*}{ Ratio } & \multirow{2}{*}{$\begin{array}{c}\text { Percent by } \\
\text { cement } \\
\text { weight }\end{array}$} & \multicolumn{2}{|c|}{ Temperature } & \multirow{2}{*}{$\begin{array}{c}\text { Extra } \\
\text { cost } \\
\left(\$ / y d^{3}\right)\end{array}$} \\
\hline & & & $\left({ }^{\circ} \mathrm{C}\right)$ & $\left({ }^{\circ} \mathrm{F}\right)$ & \\
\hline $\mathrm{CaCl}_{2}$ & - & 7 & -15 & 5 & 3.26 \\
\hline $\mathrm{NaCl}^{2}$ & - & 5.7 & -5 & 23 & 0.67 \\
\hline \multirow{3}{*}{$\mathrm{NaNO}_{2}$} & - & 6 & -5 & 23 & 11.51 \\
\hline & - & 8 & -10 & 14 & 15.34 \\
\hline & - & 10 & -20 & -4 & 19.18 \\
\hline $\mathrm{NaCl}_{2}+\mathrm{CaCl}_{2}$ & $1: 1.5$ & 7.7 & -20 & -4 & 2.51 \\
\hline \multirow{4}{*}{$\mathrm{CaCl}_{2}^{2}+\mathrm{NaNO}_{2}^{2}$} & $1: 1$ & 5 & -5 & 23 & 5.96 \\
\hline & - & 6.5 & -10 & 14 & 7.74 \\
\hline & - & 8.5 & -15 & 5 & 10.13 \\
\hline & - & 9 & -20 & -4 & 10.72 \\
\hline \multirow{4}{*}{$\mathrm{Ca}\left(\mathrm{NO}_{2}\right)_{2}+\mathrm{CO}\left(\mathrm{NH}_{2}\right)_{2}$} & $3: 1$ & 5.5 & -5 & 23 & 10.35 \\
\hline & - & 9.5 & -10 & 14 & 17.88 \\
\hline & - & 11 & -15 & 5 & 20.71 \\
\hline & - & 13 & -20 & -4 & 24.47 \\
\hline \multirow{2}{*}{$\mathrm{Ca}\left(\mathrm{NO}_{3}\right)_{2}+\mathrm{CO}\left(\mathrm{NH}_{2}\right)_{2}$} & $1: 1.5$ & 8.8 & -10 & 14 & 8.98 \\
\hline & $3: 1$ & 9 & -20 & -4 & 11.23 \\
\hline $\mathrm{Ca}\left(\mathrm{NO}_{3}\right)_{2}+\mathrm{Na}_{2} \mathrm{SO}_{4}$ & $1.2: 1$ & 6.6 & -10 & 14 & 7.11 \\
\hline \multirow{4}{*}{$\mathrm{Ca}\left(\mathrm{NO}_{2}\right)_{2}+\left(\mathrm{NO}_{3}\right)_{2}+\mathrm{CO}\left(\mathrm{NH}_{2}\right)_{2}$} & $1.5: 1.5: 1$ & 5.5 & -5 & 23 & 8.61 \\
\hline & - & 9.5 & -10 & 14 & 14.87 \\
\hline & - & 11 & -15 & 5 & 17.22 \\
\hline & - & 13 & -20 & -4 & 20.35 \\
\hline \multirow{5}{*}[\mathrm{Ca}(\mathrm{NO}_{2})_{2}+(\mathrm{NO}_{3})_{2}+\mathrm{CaCl}_{2}]{$+\mathrm{CaCl}_{2}+\mathrm{NaNO}_{2}$} & $0.33: 0.33: 0.33: 1: 1$ & 5 & -5 & 23 & 6.24 \\
\hline & - & 9 & -10 & 14 & 11.24 \\
\hline & - & 10 & -15 & 5 & 12.49 \\
\hline & - & 12 & -20 & -4 & 14.38 \\
\hline & - & 14 & -25 & -13 & 17.48 \\
\hline \multirow{4}{*}{$\mathrm{Ca}\left(\mathrm{NO}_{2}\right)_{2}+\left(\mathrm{NO}_{3}\right)_{2}+\mathrm{CaCl}{ }_{2}+\mathrm{CO}\left(\mathrm{NH}_{2}\right)_{2}$} & $0.75: 0.75: 1.5: 1$ & 9 & -20 & -4 & 9.47 \\
\hline & - & 11.5 & -20 & -4 & 12.10 \\
\hline & - & 13 & -20 & -4 & 13.68 \\
\hline & - & 14 & -25 & -13 & 14.73 \\
\hline \multirow[t]{4}{*}{$\mathrm{K}_{2} \mathrm{CO}_{3}$} & - & 6 & -5 & 5 & 14.04 \\
\hline & - & 8 & -10 & 14 & 18.72 \\
\hline & - & 10 & -15 & 5 & 23.41 \\
\hline & - & 12 & -20 & -4 & 28.09 \\
\hline $\mathrm{NaNO}_{2}+\mathrm{Na}_{2} \mathrm{SO}_{4}$ & $2: 1$ & 9 & -10 & 14 & 13.54 \\
\hline $\mathrm{NaNO}_{2}+\mathrm{Ca}\left(\mathrm{NO}_{3}\right)_{2}+\mathrm{CaCl}_{2}$ & $2.9: 1: 2.9$ & 11.5 & -10 & 14 & 14.07 \\
\hline $\mathrm{NH}_{4} \mathrm{OH}$ & - & 5.2 & -20 & -4 & 3.52 \\
\hline
\end{tabular}


much are used but, based on the Boston ready-mix price, a $75 \%$ increase represents a $\$ 46 / \mathrm{yd}^{3}\left(\$ 60 / \mathrm{m}^{3}\right)$ surcharge for including an antifreeze admixture into the concrete. That still makes antifreeze admixtures economically competitive with heating and protecting concrete.

\section{OTHER ANTIFREEZE ADMIXTURES}

Practically anything that is soluble in water will depress its freezing point. Chemical handbooks list a myriad of aqueous solutions with low freezing points, not all of which are appropriate for concrete: some are toxic, others are corrosive and many are costly.

Rather than try to pick candidate chemicals from such a list, there are several compounds being used for similar purposes in the cold regions today. For example, deicing compounds are routinely used at airports, on ships and on highways. A deicer must be cost-effective, environmentally safe, and non-corrosive, which are qualities that the ideal antifreezer must meet. Water supplies in the Arctic must be protected from freezing in normal use and during power outages. It is common practice to use nontoxic antifreeze compounds in fire hydrants. The food industry uses many water-soluble chemicals in foodstuffs. In addition, Derrington (1967) suggests over 40 chemicals that might be compatible with concrete and Matyszewski (1985) describes a factory waste as an additive. Chemicals from these sources should be considered as possible antifreeze admixtures for concrete.

\section{SUMMARY AND CONCLUSIONS}

Antifreeze admixtures have been used in foreign countries since the 1950's. Chloride salts were the first admixtures to be used in the U.S.S.R. beginning in 1951 to build retaining walls, canal structures, roads and foundations in the winter. Rapid corrosion of reinforcements caused by the chlorides, however, necessitated a search for other noncorrosive admixtures. The most common ones found in the literature today were given in Table 2.

The literature demonstrates that antifreeze admixtures will allow concrete to gain strength at belowfreezing temperatures. Strengths generally lag that of control concrete at early age, but tend to catch up or even surpass strengths of control samples in time.

The strength gains were based on laboratory-size specimens that do not necessarily represent field conditions. Under the rapid-freezing conditions of the laboratory, ice formations in limited amounts had little, if any, adverse effects on the ultimate strength of concretes made with antifreeze admixtures. In the field, moisture is more likely to migrate within the concrete. The result is that ice lenses, which may form near the surface, may cause spalling when warm weather returns. The rate of cooling, as discussed earlier, plays an important role in this potential problem.

Antifreeze admixtures, except for potash, act to increase the freeze-thaw resistance of concrete compared to normal non-air-entrained concrete. Although entrained air is expected to increase the freeze-thaw resistance of antifreeze concrete, as it does with normal concrete, little evidence is available to substantiate that. One field test suggested that there may be a problem with finding air-entraining admixtures that are compatible with the various antifreeze admixtures.

The admixture crystals that remain in the concrete once it is cured may promote structural breakdown of the concrete under repeated wetting and drying cycles.

The literature encourages cautious confidence in using antifreezers in concrete placed in below-freezing weather. However, it must also be kept in mind that the tests conducted to date are only valid for the cements used. Laboratory tests supported by field demonstrations are needed to develop this technology for U.S. cements and construction practices.

\section{NEEDED RESEARCH}

In 1977 Mironov stated that, in spite of the success achieved in recent years in studying chemical additives, many questions still remain. This author believes that is a valid statement for the U.S. today, particularly when it is considered that the U.S. has little testing and field experience with antifreeze admixtures.

As a minimum, the following laboratory evaluations should be conducted on the most promising admixtures mentioned in the literature.

1. Examine strength gain at low temperatures with U.S. cements in compression and in tension.

2. Evaluate freeze-thaw durability with and without air-entraining admixtures.

3. Determine the critical ice content at early age, looking at percent ice content versus 28 -day strength.

4. See how the admixtures interact with U.S. cements; determine the hydration products, degree of hydration and corrosivity.

It is recognized that the proposed tests will not, by themselves, provide the information necessary to recommend wholesale use of antifreeze admixtures. They will, however, provide a basis upon which to evaluate antifreezers, particularly as they become commercially available. 


\section{LITERATURE CITED}

ACI (1985) Admixtures for concrete. ACI 212.1R-81. In ACI Manual of Concrete Practice. Part 1: Materials and General Properties of Concrete. Detroit, Michigan: American Concrete Institute.

ACI (1988) Cold weather concreting. ACI 306R-88. Detroit, Michigan: American Concrete Institute.

ASTM (1984) C666-84, Standard test method for resistance of concrete to rapid freezing and thawing. 1985 Annual Book of ASTM Standards, Section 4. Philadelphia: American Society for Testing and Materials.

Bazhenov, G.L., V.S. Isayev and V.T. Nikulin (1974) Antifreeze admixture dosages for concretes and mortars. Gorky: The V.P. Chkalov Construction Engineering Institute.

Cottringer, P. and H.S. Kendall (1923) Use of calcium chloride as a protection against freezing of concrete. Concrete, April.

Derrington, C.F. (1967) Investigation of use of antifreeze compounds in concrete and mortar. U.S. Army Waterways Experiment Station, Miscellaneous Paper no. 6-871.

Engineering News Record (1989) ENR materials prices, August 3.

Golobov, A.V., V.S. Samchenko, E.Ye. Melamed and P.U. Boyko (1974) Concretes with antifreeze admixtures. USA Cold Regions Research and Engineering Laboratory, Draft Translation 445.

Goncharova, L.S. and F.M. Ivanov (1975) The properties of concretes containing antifreeze admixtures. In Proceedings of the 2nd International Symposium on Winter Concreting, 14-16 October. Vol. 1. Moscow: Stroiizdat, p. 69-71 (in Russian).

Grapp, A.A., V.B. Grapp and A.S. Kaplan. (1975) The structure and cold resistance of concretes containing antifreeze admixtures. In Proceedings of the 2 nd International Symposium on Winter Concreting, 14-16 October: Vol. 1. Moscow: Stroiizdat, p. 60-68 (in Russian).

Jokela, J., L. Kivekas, H. Kukko, J. Ratvio and E. Rissanen (1982) Arctic Concrete Technology. Technical Research Centre of Finland (VTT), Concrete and Silicate Laboratory, Research Reports.

Kivekas, L., S. Houvinen and M. Leivo (1985) Concrete under arctic conditions. Technical Research Centre of Finland (VTT), Concrete and Silicate Laboratory, Research Report 343.

Korhonen, R. (1987) Experimental construction in Kilpisjarvi: experience of transportation of frost resistant concrete. Technical Research Centre of Finland (VTT), Building Laboratory, Research Note 808.

Korhonen, R. (1987) Kavelalainen Building Project: Pouring of the foundations with antifreeze concrete.
Technical Research Centre of Finland (VTT), Building Laboratory, Research Note 820.

Kostyayev, P.S., Ye.S. Odintsov, T.A. Petropavlovskaya, Ye.N. Pochernyayeva, A.I. Kofman, V.P. Korobeynikov and V.N. Sidorov (1971) Research on concretes and mortars with anti-freeze additives for bridge construction. Spetsial'nyye tsementy i betony, Issue 351, Moscow, p. 136-156 (in Russian).

Krylov, B.A., A.V. Lagoida and G.P. Apostolova (1979) Critical strength of concretes with antifreeze admixtures. Beton $i$ Zhelezobeton (Concrete and Reinforced Concrete), no. 12, p. 27-28 (in Russian).

Kukko, H. and I. Koskinen (1988) RILEM recommendations for concreting on cold weather. Technical Research Centre of Finland (VTT), Concrete and Silicate Laboratory, Research Note 827.

Kuz'min, E.D., V.V. Virskaya and V.A. Kruglov (1976) Hydro Technical Construction (Gidrotekhnicheskoe Stroitel'stov), no. 11, p. 17-19, November (in Russian).

Kuzmin, Y. D. (1976) Concretes with Antificeze Admixtures. Kiev: Budivelnik Publishing House.

Low Temperature Building Sciences Institute (1979) $\mathrm{NaNO}_{2}-\mathrm{NaSO}_{4}$ Combined additive in cold concrete. Low Temperature Building Sciences Institute, Heilonjiang, People's Republic of China. USA Cold Regions Research and Engineering Laboratory, Draft Translation 717.

Matyszewski, T. (1985) Production of the sand-aggregate concrete at freezing temperature. Third international RILEM symposium on winter concreting, Technical Research Centre of Finland (VTT), Concrete and Silicate Laboratory, VTT Symposium 61.

Miettinen, H., J. Vourinen and H. Kukko (1981) Comparison of codes concerning winter concreting in Finland and in the Soviet Union. Technical Research Centre of Finland (VTT), Concrete and Silicate Laboratory, Research Note 11.

Mironov, S.A., A.V. Lagoyda and Ye. N. Ukhov (1976) Curing concrete with chemical additives in freezing weather. USA Cold Regions Research and Engineering Laboratory, Draft Translation 545.

Mironov, S.A. (1977) Theory and methods of winter concreting. USA Cold Regions Research and Engineering Laboratory, Draft Translation 636.

Mironov, S.A. and V.D. Demidov (1978) Cohesion of new concrete with old under winter conditions. Hydrotechnical Construction (Gidrotekhnicheskoe Stroitel'stov), no. 1, p. 16-18. (Translation from Plenum Publishing Corp.)

Mironov, S.A., O.S. Ivanova and Yu.B. Volkov (1979)

Concrete with new anti-freeze admixtures. Concrete and reinforced concrete (Beton i Zhelezobeton), no. 7, p. 14-15 (in Russian). 
Mironov, S.A. and B.A. Krylov (1956) Concrete with chloride salts in winter conditions. Winter Concreting, Theory and Practice, RILEM Symposium, Session D, Copenhagen, February, p. 55-93.

Ovcharov, V.I. (1972) Effective life of corrosion inhibitor-containing concretes and mortars prepared under winter conditions. Tsentr. Nauchno-Issled. Inst. Stroit. Konstr. im. Kucherenko (in Russian).

Sheikin, A.E., P.S. Kostyaev, L.M. Dobshits, V.M. Smolyanskii, N.K. Rozental, O.S. Ivanova and S.I. Pchelkin (1980) Study of the corrosion of steel reinforcement in concretes containing certain additives. $T r$. Institute Inzh. Zheleznordorozhn. Transp., 662: 35-44 (in Russian).

Sizov, V.N. (1956) Concrete, able to harden in frost. Winter Concreting, Theory and Practice, RILEM Symposium, Session E, Copenhagen, February, p. 20-24. Stormer, C. D. (1970) Cold concrete. USA Cold Regions Research and Engineering Laboratory, Technical

\section{Report 220.}

Virmani, Y. P., K. C. Clear and T. J. Pasko, Jr. (1983) Time-to-corrosion of reinforcing steel in concrete slabs. Volume 5, Calcium nitrite admixture or epoxy-coated reinforcing bars as corrosion protection systems. Federal Highway Administration report FHWA/RD-83-012.

Virmani, Y. P. (1988) Time-to-corrosion of reinforcing steel in concrete slabs. Volume 4, Calcium nitrite admixture. Federal Highway Administration report FHWA-RD-88-165.

Yang, Y. (1982) Strength development of concrete placed in frozen soil and the thermal effects. In Proceedings, 3rd International Symposium on Ground Freezing, 22-24 June, Hanover, N.H. USA Cold Regions Research and Engineering Laboratory.

Yates, C.Y. (1941) Effects of calcium chloride on portland cements and concretes. Highway Research Board, Proceedings, 21: 288-293. 
